\title{
酸性溶液中における $\mathrm{Al} の$ \\ アノード酸化時の電圧-電流特性の解釈
}

\author{
海老原 健*，高橋 英明*，永山 政一* \\ Interpretation of the Voltage-Current Characteristics \\ Observed When Anodizing Aluminum in Acid Solutions
}

Ken EBIHARA*, Hideaki TAKAHASHI*, and Masaichi NAGAYAMA*

An attempt is made to explain steady voltage-log current $\left(E_{a}-\log i_{a}\right)$ curves obtained for the anodization of aluminum in acid solutions, by applying a theory so far reported for high-field ion conduction in crystalline solids. The theory is modified to some extent by taking into account two factors: the semi-spherical shell structure of the barrier layer by which the applied voltage is sustained, and the formation and repair of defects in the barrier layer which are appreciable at higher voltages. The interpreation of $E_{a}-\log i_{a}$ behavior, including the effect of temperature, is quite satisfactory.

\section{1. 緒言}

酸性溶液中でアルミニウムの多孔質アノード酸化皮膜 を生成するさい，電流密度 $i_{a}$ の対数と電圧の定常值 $E_{a}$ との間には S字形曲線の関係が成立するが，その解釈に ついてはこれまでほとんど報告がない。本研究では，従 来の“バリヤ一層内のイオン移動に関する理論”を基礎 にし，皮膜の形状を考虑することによりこの $\log i_{a}-E_{a}$ 特性の説明を試みた。

\section{2. $\log \boldsymbol{i}_{a}-\boldsymbol{E}_{a}$ 特性および多孔質皮膜の形状}

検討に用いた $\log i_{a}-E_{a}$ の実測值（図 1 (a) および(b)） は前報1),2)に述べたものを再録した。これらは硫酸溶液 およびシェウ酸溶液中の $\mathrm{Al}$ に定電流 $i_{a}$ を与えて求めた もので定常的な電圧 $E_{a}$ の值をプロットしてある。ただ し， $i_{a}$ が大きな場合には定常状態に拈いても電圧の微少 な振動がみられ， $i_{a}$ がさらに大きければ一応の定常值に 至ったあとも電圧が徐々に上昇してゆく(図 2 )。図 1 (a) の $E_{a} \geq 16 \mathrm{~V}$, 図 1 (b)の $E_{a} \geq 40 \mathrm{~V}$ の領域では, この一応 の定常值を $E_{a}$ とした。図 1 の $\log i_{a}-E_{a}$ の曲線は後述 の計算により求めた理論曲線である。図 3 は既報 ${ }^{1), 2)}$ の 結果を整琵したもので，硫酸皮膜扎よびシュウ酸皮膜の 構造, すなわちセル半径 $(R)$, 孔の半径 $(\boldsymbol{r})$, およびバ リヤー層の厚さ $\left(\hat{o}_{b}\right)$ 究 $E_{a}$ の関数として示してある。こ れらの值は電解液の濃度特よび電流密度には直接依存し ない。バリヤ一層は後述のように椀状になっているが,

*北海道大学工学部(宇060 札幌市北区北13条西8丁目) Fac. of Eng., Hokkaido Univ. (Kita-13, Nishi-8, Kita-ku, Sapporo-shi 060)
その形状の詳細は図 3 の結果にもとついて推定した。

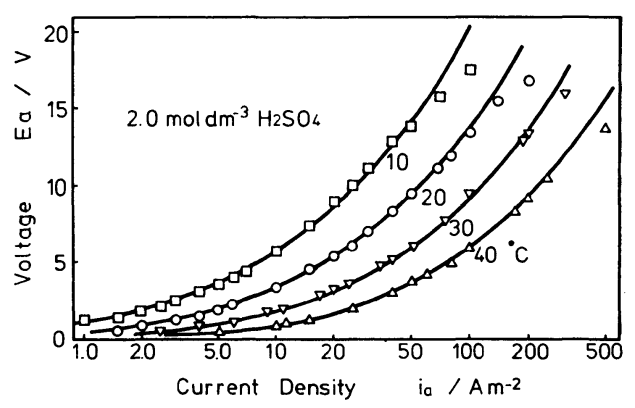

Fig. 1(a) Relationships between $E_{a}$ and $i_{a}$ meaured in a sulfuric acid solution at differ ent temperatures. Solid curves are drawn by calculation with equation (10).

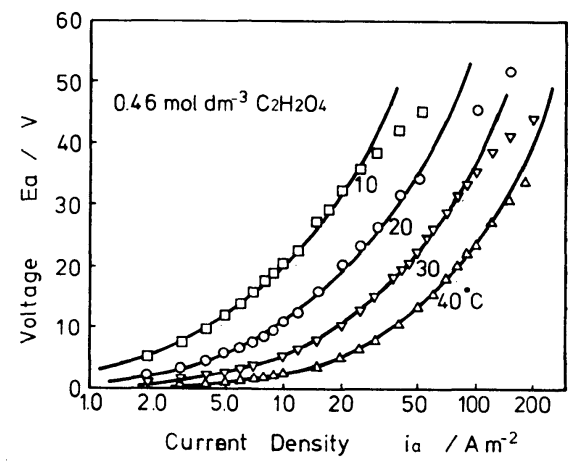

Fig. 1(b) Relationships between $E_{a}$ and $i_{a}$ measured in a oxalic acid solution at different temperatures. Solid curves are drawn by calculation with equation (11). 


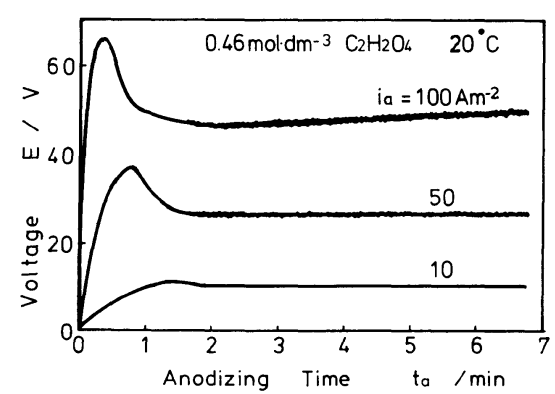

Fig. 2 Changes in the voltage with anodizing time.

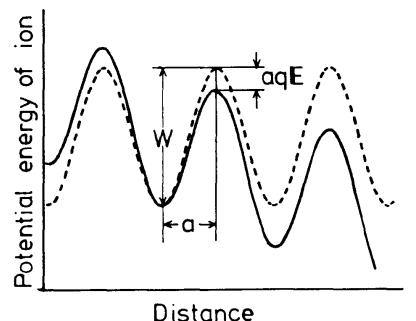

Fig. 4 Potential energy-distance relationships for a mobile ion in a crystalline solids. Solid and broken curves are the relationships expected in the presence and absence of electric field, E, respectively. Here, $\mathrm{W}$ is the activation energy for the movement, $\mathrm{a}$ is the activation distance and $\mathrm{q}$ is the charge associated with the ion.

\section{3. イオン電流と電場強度に関する理論}

皮膜を通しての電流の通過はイオン結晶中をイオンが 移動することに相当する。イオンの移動は格子欠陥を介 して起こるものと考光られる。格子欠陷位置に括けるイ オンのエネルギー（谷底）䟣び隣接する 2 つの格子欠 樎の中間位置に怙けるイオンのエネルギー（山頂）が電 場によって変化する様子をモデル的に図 4 亿示す。この 2つのエネルギーの差はイオン移動の障壁エネルギーで

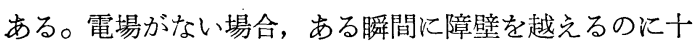
分な熱的エネルギーを持つイオンの数の割合は, 反応速 度論より $\exp (-W / k T)$ で与兄られる(Wは障壁のエネ ルギー（活性化エネルギー), $k$ はボルッマン定数， $T$ は 絶対温度)。イオンの移動を促進する方向に電場をかけ た場合には，障壁エネルギーの高さは電場強度を $E(=$ 電圧／距離）とすると $W-a q E$ となる。ここで $a$ は活性 化距離, すなわち図 4 のエネルギーの谷底と山頂の位置

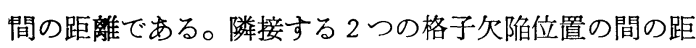
離は，障壁の山の形を対称と考えると $2 a$ になる。また $q$ はイオンの電荷数であり, $a q E$ はエネルギー障壁の低 下量である。欠陷位置にあるイオンは振動数レで振動し ており，このンは通常の速度式に見られる頻度因子に相

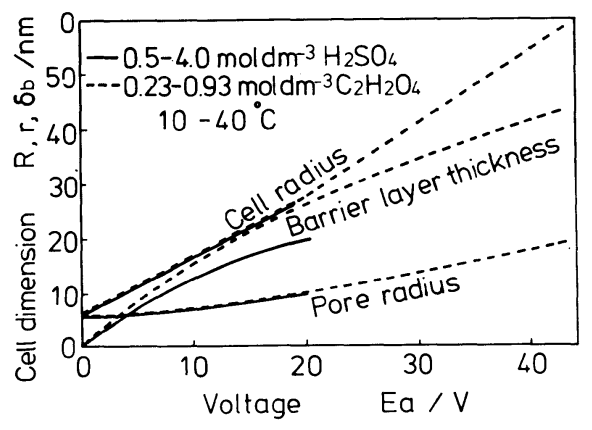

Fig. 3 Variations in the cell radius $(R)$, pore radius $(\mathbf{r})$, and barrier layer thickness $\left(\delta_{b}\right)$ with voltage $\left(\mathrm{E}_{a}\right)$ measured for films formed in sulfuric acid and oxalic acid solutions.

当する。単位面積当たりのイオンの移動速度, すなわち 電流密度は, 単位体積当たりの可動イオン数を $n$ とする と,

$$
i=2 a q n \nu \exp \left(-\frac{W-a q E}{k T}\right)
$$

ここで $\exp (-(W-a q E) / k T)$ はェネギー障壁を越 える確率に相当し，これに2aqnをかけたものが $i$ 亿相 当する。な和(1)式では，充分に電場が高くて逆方向の 電流を無視している。

このイオン移動の理論は種々の金属のアノード酸化皮 膜について広く適用されて找り ${ }^{52}$ 13)，亲た酸化物の内 部のみではなく酸化物／金属界面層拉よび溶液／酸化物 界面層にも適用されている ${ }^{97,13)}$ 。アルミニウムのバリヤ 一型アノード酸化皮膜について定電流下の電圧一時間特 性の説明に(1) 式を適用するさい, Günterschultz, Bet $z^{5)}$ は $W=1.8 \mathrm{eV}, a=3.5 \mathrm{~A}(q=3 \mathrm{e}), 2 a n q \nu=3.62 \times$ $10^{-27} \mathrm{Am}^{-2}$ とし, Charlesby ${ }^{6)}$ は $W=1.55 \mathrm{eV}, a=2.5 \mathrm{~A}$ $(q=3 \mathrm{e}), \nu=10^{-12} \mathrm{sec}^{-1}, n=10^{13} \mathrm{~cm}^{-1}$ といら值を与兄て いる。 $a$ の值は，もともとイオン結唱の格子定数の $1 / 2$ に相当するものと考光られて拈り, Verwey ${ }^{4)}$ は酸化物 の構造を $\gamma^{\prime}-\mathrm{Al}_{2} \mathrm{O}_{3}$ と考劣て $\boldsymbol{a}=0.988 \mathrm{~A}$ と予想している。 しかし，(1) 式を適用して得られた前述の $\boldsymbol{a}$ 值はかなり 異なっている。現在をでこの理論はアルミニウムの多孔 質アノード酸化皮膜には適用されていないが，多孔質皮 膜も基本的にはイオン結晶であり4)，この理論は適用で きるものと考えられる。

\section{4. アルミニウム多孔翼アノード 酸化皮膜に対する理論の適用}

多孔質皮膜は酸性溶液中でアノード酸化することによ り生成する。このとき $\log i_{a}$ と $E_{a}$ の定常関係は図 1 の ようなS字形になるが，この挙動を支配するものは孔の 底にあるバリヤー層である。以下 3 節で述べた理論を適 
用してこの $\mathrm{S}$ 字形分極挙動を説明するが，そのさい $2 つ$ の点が問題になるであろう。

\section{1) 酸化物の溶解}

$i_{a}$ 扰よび $E_{a}$ の定常状態に沶いては， $E_{a}$ の漂と儿ど がバリヤ一層にかかって扬り, バリヤ一層をイオン電流 $i_{a}$ が通過している。バリヤ一層では酸化物の生成と溶解 とが同時進行してその厚さ $\delta_{b}$ が定常に保たれている。 ここで溶解反応は “酸化物の生成に引き続いて起こる二 次的反応”であって，それによっで゙リヤ一層の厚さが 定常に保たれるといら点でむしろ系を単純なものにして いる。すなわち，ある定常の厚さの皮膜を通して一定電 流が流れているということであって (1) 式の適用にはま ったく問題がない。溶解は直接的には考慮する必要がな いのである。Dignam ${ }^{19)}$ は溶解が存在するさいに(1)式 の適用の可能性を理由むなく否定しているが，これは明 らかに誤りと思われる。

2）バリヤー層の形状

バリヤー層の形状は平板ではなく，椀状であることが わかっている。（1）式はこれを考慮沉れて適用しなけ ればならない。問題点は椀状であるために深さ位置に応 じて電流の通過する面積が異なり，電流密度 $i_{a}$ および 電場強度 $E$ の值が異なることである。

い亡バリヤ一層に対し溶液/酸化物界面からの距離を $x$ とする。溶液／酸化物界面では $x=0$, 酸化物／金属界 面では $x=\delta_{b}$ であり,$x=x$ の面を $x$ 面とよぶ。 $x$ 面によ って $E$ が異なることを考慮すると，定常状態に执いて皮 膜にかかる電圧 $E_{a}$ は,

$$
E_{a}=\int_{o}^{\delta_{b}} E_{x} d x
$$

$E_{x}$ は $x$ 面に括ける電場強度である。特定の $x$ 面につい て(1)式を適用すると，

$$
i_{x}=2 a q n \nu \exp \left(-\frac{W-a q E_{x}}{k T}\right)
$$

ここで $i_{x}$ は $x$ 面に持ける電流密度である。皮膜の一つ のセルについての $x$ 面の画積を $S_{x}$ とし, 試料の単位面 積あたりの孔数（をたはセル数）を $N\left(=\pi^{-1} R^{-2}\right)$ とする と,

$$
i_{x}=i_{a} /\left(N \cdot S_{x}\right)
$$

$S_{x}$ は図 5 のように頂角 $\theta$ の円錐できりとられた球の表 面積の一部に相当し, 次の回転積分の式によって計算で きる。

$$
S_{x}=2 \pi \int_{\left(\boldsymbol{r} \delta_{b} / \delta_{p}+x \sqrt{1-\left(\delta_{p} / \delta_{b}\right)^{2}}\right.}^{\left(r \delta_{b} / \delta_{p}+x\right)}\left(r \delta_{p}+x\right) d y . .
$$

ここで $\delta_{p}$ はセル壁の厚さで $R-\boldsymbol{r}$ に等しい。(2) (5) 式 を組み合わせて積分すると，

$$
\begin{aligned}
& \log i_{a}=\frac{a q E_{a}}{2.303 \delta_{b} k T}+\log (2 a q n \nu)-\frac{W}{2.303 k T} \\
& +\log \left(\delta_{b}-\sqrt{\delta_{b}^{2}-\delta_{p}^{2}}\right)+\log \delta_{b}
\end{aligned}
$$

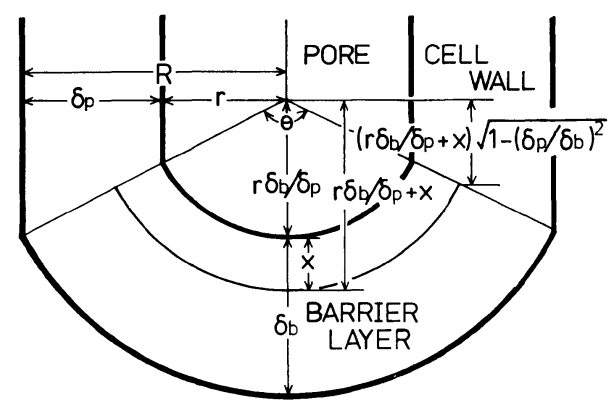

Fig. 5 Schematic model showing the shape of barrier layer.

$+2(R \log R-r \log r) / \delta_{b}+2 \log \left(R \delta_{b}\right)-1.699$ (6) ここで $a, q, n, \nu, W$ の值は同じ溶液条件では定数であ るとすう。そうすれば， $\delta_{b}, \delta_{p}, R$ 扎よびrはいずれも $E_{a}$ の々の関数（図3）なので, $\log i_{a}$ は $E_{a}$ の関数とし て記述できる。ここで，図 3 の突験値を用い， $R, r, \delta_{b}$ は $E_{a}$ の関数として次のように表わされる。

- 硫酸溶液の場合

$$
\begin{aligned}
& R=\left(6.05+E_{a}\right) \times 10^{-9}(m) \\
& r=1.012 E_{a}{ }^{-0.28} R(m) \\
& \delta_{b}=1.78 E_{a^{0}}{ }^{.83} \times 10^{-9}(m) \\
& \text { ・ ウウ酸溶液の場合 } \\
& E_{a} \leq 20 \mathrm{~V} \\
& R=\left(7.27+E_{a}\right) \times 10^{-9}(m) \\
& r=0.977+E_{a}{ }^{-0.32} R(m) \\
& \delta_{b}=2.07 E_{a^{0.83}} \times 10^{-9}(m) \\
& E_{a} \geq 20 \mathrm{~V} \\
& R=\left(-1.46+1.45 E_{a}\right) \times 10^{-9}(m) \\
& r=0.643 E_{a}{ }^{-0.18} R(m) \\
& \delta_{b}=2.07 E_{a^{0.83}} \times 10^{-9}(m)
\end{aligned}
$$

(7)〜(9)式の関係括よび， $i_{a}$ 虽よび $E_{a}$ の审測值（図 1) を(6)式へ代入し次式を得た。

-2. $0 \mathrm{~mol} \cdot \mathrm{dm}^{-3}$ 硫酸溶液の場合

$$
\log i_{a}=1000 E_{a^{0.17}} / T+10.89-4270 / T+f_{E a}
$$

・ $0.46 \mathrm{~mol} \cdot \mathrm{dm}^{-3}$ シュウ酸溶液の場合

$$
\log i_{a}=670 E_{a^{0.17}} / T+10.14-3780 / T+f_{E a}
$$

ここで $f_{E a} a$ は(6)式右辺の 4 項以降をまとめたもので(7) 〜 (9)の関係を用いてその数值を知りらる。 $f_{E a}$ 值は, 硫酸の 場合には $E_{a}$ とともに減少し，1２0Vの範囲で -1.141〜-1.378之なる。シュウ酸の場合，1〜20Vで は $E_{a}$ とともにー1.141〜ー1.378をで減少し，20Vを越 光ると上昇して $E_{a}=50 \mathrm{~V}$ ではー1.385となる。いずれに しろ(10)乩よび(11)式によって表わされる $\log i_{a}-E_{a}$ の 関係(図 1 実線) に実測の関係とよく一致している。

(10)，(11)式と(6)式を比較することにより(6)式の各 定数が求められる。 
Table 1 Values of parameters obtained for different electrolyte concentrations.

\begin{tabular}{l|c|c|c|c}
\hline & $\mathrm{C} / \mathrm{mol} \mathrm{dm}^{-3}$ & $\mathrm{a} / 10^{-10} \mathrm{~m}$ & $\mathrm{~W} / \mathrm{eV}$ & $2 \mathrm{aqn \nu} / 10^{-12} \mathrm{Am}^{-2}$ \\
\hline & 0.5 & 1.278 & 0.847 & 5.51 \\
$\mathrm{H}_{2} \mathrm{SO}_{4}$ & 1.0 & 1.374 & 0.847 & 5.51 \\
& 2.0 & 1.471 & 0.847 & 4.28 \\
& 4.0 & 1.569 & 0.847 & 3.03 \\
\hline & 0.23 & 1.065 & 0.751 & 1.05 \\
$\mathrm{C}_{2} \mathrm{H}_{2} \mathrm{O}_{4}$ & 0.46 & 1.142 & 0.751 & 0.777 \\
& 0.93 & 1.179 & 0.751 & 0.712 \\
\hline \hline
\end{tabular}

-2. $0 \mathrm{~mol} \cdot \mathrm{dm}^{-3}$ 硫酸の場合

$W=0.85 \mathrm{eV}, a=1.48 \mathrm{~A}(q=2.4 \mathrm{e}), 2 a q n \nu=4.23 \times 10^{12}$ $\mathrm{Am}^{-2}$

・ $0.46 \mathrm{~mol} \cdot \mathrm{dm}^{-3}$ シュウ酸の場合

$W=0.75 \mathrm{eV}, a=1.14 \mathrm{~A}(q=2.4 \mathrm{e}), 2 a q n \nu=7.53 \times 10^{11}$

$\mathrm{Am}^{-2}$

ここで $a q$ の積の值は決定できるが， $a$ の值を求めるに は $q$ の值を知る必要がある。前述の $q=2.4 \mathrm{e}$ といら值は 次のようにして求めたものである。まずバリヤ一層内で 電荷を 運びうるイオン種は $\mathrm{O}^{2-}$ イオンと $\mathrm{Al}^{3+}$ イオンで あり，これらは皮膜内を逆方向に，それぞれ酸化物／金 属界面および酸化物／溶液界面に向かって移動する。 $\mathrm{O}^{2-}$ イオンの 移動は $q=+2 \mathrm{e}$ の電荷が( $\mathrm{Al}^{3+}$ イオンの $q=+3 \mathrm{e}$ の電荷とともに）酸化物/溶液界面に移動する ことと等価である。ここで $\mathrm{O}^{2-}$ イオンお゙よび $\mathrm{Al}^{3+}$ イオ ンの輸率はそれぞれ 0.6 特よびで0.4あるとし注1)，その 加重平均をとると電荷 $q=2.4 \mathrm{e}$ ，この電荷をるつカチオ ンが輸率 1.0 で酸化物/溶液界面に向かって動くと考え ればょい。電解夜濃度を種々変えた場合について(6)式 の各定数を計算し表 1 亿示した。一般に電解質濃度が増 加すると $a$ が増加する。これは溶液の濃度が高くなるほ ぞ生成する皮膜がより 無定形になることを意味してい る。しかしこの研究に颃いて算出した多孔質皮膜の $a$ 值 は従来バリヤ一型皮膜について報告されている $a$ 值 ${ }^{5>, 6)}$ と比べてかなり小さく，多孔質皮膜を構成する酸化物は むしろそれだけ結晶性が良いことを示している。

さて，図 1 に㧤いて $E_{a}$ の高い領域では， $E_{a}$ の上昇と ともに実測の $i_{a}$ が 理論的曲線上の $i_{a}$ 值よりも大きくな る。これは垁測の曲線が $\mathrm{S}$ 字形で一つの変曲点を持つの に対し, 理論式(10), (11)の $\log i_{a}$ が $E_{a}$ の単調增加関 数であることによる。アノード酸化のさい，イオン電流

注 1 ）輸率の值は電流密度化応して多少変化すること が判っている ${ }^{16)}$ 。 $\mathrm{Al}^{3+}$ とつては $i_{a}$ の大きい活ど小 さくなり極端な場合には 0.2 程度になる。しかし， そのような場合でも平均的な $q$ 值は+2.2 $\mathrm{e}$ 程度であ り，あまり大きな変化はないと言える。
が定常的にバリヤ一層を横切って流れるとすれば $\log i_{a^{-}}$ $E_{a}$ の関係は理論式に従らべきであり，実測の $i_{a}$ が 理論 值より大きいのはバリヤー層の局所的かつ動的な破壊の ためでその修復のために余分な電流が流れるためと考兄 る。その根拠は次のようである。

1) 電圧の振動現象

バリヤー層の破壊と修復の微候は, 電圧の振動によっ て示される (図 2)。振動は硫酸溶液の $E_{a}=12 \mathrm{~V}$ の条件 拉よびシュウ酸溶液での $E_{a}=25 \mathrm{~V}$ の条件ですで認め られるが，これらの条件では修復に要する余分の電流は 平均的に 極めて小さく, $\log i_{a}-E_{a}$ の関係は事実上理論 曲線の上にのっている。このような皮膜破壊（プレーク ダウン）とその修復は中性溶液中の $\mathrm{Al}$ に高い電压を与 えてアノード酸化する場合（バリヤー型）にもしばしば 見受けられる。

\section{2 ）バリヤー層内の電場強度}

硫酸皮膜が $E_{a}=15 \mathrm{~V}$ で生成する場合およびシュウ酸 皮膜が $E_{a}=30 \mathrm{~V}$ で生成する場合, $E_{a} / \delta_{b}$ として求めた平 均的な電場強度はそれぞれ $1.1 \times 10^{7} \mathrm{Vcm}^{-1}$ 抽よび $1.0 \times$ $10^{7} \mathrm{Vcm}^{-1}$ である。しかし電場強度の值は図 5 亿示すよ らにバリヤ一層の深さ位置によって異なり溶液／酸化物 界面の近くでもっとも大きい。皮膜の破壊（ブレークダ ウン) はバリヤー型皮膜の場合, 皮膜厚によっても異な るが， $0.5 \times 10^{7} \sim 1.2 \times 10^{7} \mathrm{Vcm}^{-1}$ 程度の電場強度に上っ て誘起されるといら ${ }^{15)}$ 。したがって多孔質皮膜生成の場 合にも電場強度の面から考えて，バリヤ一層の破壊が特 に溶液との界面付近で起こる可能性がある。

3）金属/酸化物界面のセ儿構造の乱れ

硫酸皮膜が $E_{a} \geq 16 \mathrm{~V}$ で生成する場合およびシュウ酸 皮膜が $E_{a} \geq 40 \mathrm{~V}$ で生成する場合には，電圧は一応の定 常に達した後も振動しながら徐々に上昇する。このよう な条件下で生成した皮膜の金属/酸化物界面に打辇る ル構造のパターンには不規則な部分がみられそこでは 酸化物が金属層に深くはいり込んでいる。これも皮膜の 局所破壊・修復の結果であるう。

4) シュウ酸皮膜の着色

シュウ酸皮膜の場合， $E_{a}$ が $25 \mathrm{~V}$ を越えると着色しは じめる。この電圧は定常状態の電圧が振動を始める電圧 と一致している。この電圧より高い $E_{a}$ 領域では, 着色 物質の生成を可能にする副次的な反応が起こると考兄ら れる。この反応は皮膜の破壊に関連するものであるら が，その機構は不明である。

以上説明したように， $E_{a}$ の十分高い条件ではバリヤ 一層の局所的かつ動的な破填が起こりその修復のため余 分の電流が流れるが, 時間 $t_{a}$ の経過とともにバリヤ一層 の弱点が次第に減少し均質化するため破壞が起こりにく くなる。すなわち $i_{a}$ 一定の下では $E_{a}$ が次第に増大して 理論曲線上の值に近づいてゆくことが予想されるが，こ 


\section{れは実験事笑と一致している（図 2 )。}

以上, このようにして硫酸溶液中でアノード酸化によ り多孔質皮膜が生成するさいにみられる $\log i_{a}-E_{a}$ の挙 動はらまく説明できたものと考える。また図 1 (a)拉よび (b)に示した各 4 本の曲線はそれぞれ(10)，(11)式の温度 項に実験温度を代入して描いたもので溶液温度の $\log i_{a^{-}}$ $E_{a}$ 特性におよぼす効果を理論的に良く説明しており, (10)，(11)式の妥当性を裏書きしているといえよう。

(1983-8-25 受理)

本論文中非 SI 単位の SI 単位に対する換算表

\begin{tabular}{|c|c|c|}
\hline 量 & 単位記号 & SI 単位による值 \\
\hline エネルギー & $\mathrm{eV}$ & $1 \mathrm{eV}=1.6022 \times 10^{-19} \mathrm{~J}$ \\
\hline 長 & A & $1 \mathrm{~A}=10^{-10} \mathrm{~m}$ \\
\hline
\end{tabular}

文献

1) 海老原健, 高橋英明, 永山政一：金表誌，32, 156 (1982)

2 ) 海老原健, 高橋英明, 永山政一; 金表誌, 34, 548 (1983)

3) 斎藤譲一, 池谷正志, 高橋俊郎; 金表誌, 27, 511 (1976)
4) E.J.W. Verwey; Physica, 2, 1059 (1935)

5) V.A. Günterschultz, H. Betz; $A$ Physik, 92, 367 (1934)

6) A. Charlesby; Proc. Phy. Soc., 66 B, 317 (1953)

7 ) L. Young; Anodic Oxide Films, (Academic Press, London, 1961)

8) H.A. Johansen, G.B. Adams. Jr., and P.V. Rysselberghe; J. Electrochem. Soc., 104, 339 (1957)

9) N. Cabrera and N.F. Mott; Rep. Prog. Phys., 12, 163 (1948)

10) G.C. Wood and A.J. Brook; Nature, 209, 773(1966)

11) C. Parsons and G.C. Wood; Corr. Sci., 9. 367(1969)

12) G.C. Wood and S.W. Khoo; J. Appl. Electrochem., 1, 189 (1971)

13) J.F. Dewald; J. Electrochem. Soc., 102, 1 (1955)

14) M.J. Dignam; Oxides and Oxide Films Vol. 2, (Marcel Dekker, Inc., New York, 1973)

15) V.F. Korzo; Soviet Physics-Solid State, 11, 2469 (1970)

16）未発表 